\title{
Promoting the Products Offered by "La Lisa Hotel" with an Effective Promotional Video
}

\author{
Yoko Amirudin \\ English Department, Faculty of Languages and Literature, Petra Christian University, Siwalankerto 121- \\ 131, Surabaya 60236, INDONESIA \\ E-mail: m11413029@john.petra.ac.id
}

\begin{abstract}
Ayola La Lisa is a a 3.5 star hotel which is located at Nginden street no 82. This hotel has 121 rooms, 4 meeting rooms, a pool, a restaurant, a coffee shop, and etc. Moreover, this hotel has more spacious rooms than its rivals and one meeting room that can accommodate up to 200 people. The main problem that $\mathrm{La}$ Lisa currenly facing is the potential customers did not give positive feedback while the sales team offered the products. Most importantly, this promotional tool failed to project La Lisa uniqueness. Because of this problem, La lisa could not get the attention from as potential customers mostly from all over Surabaya such as government officers. Therefore, the solution of the problem is to make a promotional video. With this video, the potential customers will be more interested when they see motion pictures highlighting the unique selling points, rarther than just a brochure. The unique selling points that will be highlighthed is to focus on the private meeting room and its other supporting facilities such as the lunch, the rooms, and the ambience. By having this video, the sales and marketing team will be easier to promote the hotel more effectively to its potential customers.
\end{abstract}

Keywords: promotion, branding, unique selling point (USP), promotional video

\section{INTRODUCTION}

The company where I did my internship at La Lisa Hotel. La Lisa Hotel is a 3.5 star hotel which is located on Nginden street number 82. This hotel has 121 rooms, 4 meeting rooms, pool, restaurant, coffee shop, and etc. This hotel has more spacious rooms than its rivals and one meeting room that can accommodate up to 200 people.

In La Lisa there are two main jobs which are sales and marketing. However, for my internship program, I will focus on the sales program. Based on my observation, there are 2 main competitors of La Lisa. The first one is Ibis Style. Ibis has played a big role in Indonesia's market. Ibis also has a well known brand image that can easily take down any other competitors. Other than Ibis there is also Santika. Looking at the price, La lisa and Santika's has similar price point. The price range for La Lisa starts from Rp 450.000 - 750.000, while Santika starts from Rp. 550.000 - 850.000. Looking at this fact, it appears that people tend to think twice which is better in term of price.

Within the three months of my internship in La Lisa, I have found a problem concerning the Hotel. The main problem that La Lisa currently facing is a potential customer did not give a good feedback while sales team offered La Lisa's product. The promotional tool that La Lisa's sales team are using right now only explains the products in general with photos that are not taken by professionals through their booklet. Most importantly, the booklet failed to project La Lisa's uniqueness. Because of this problem, La Lisa could not the attention of new potential customers from all over Surabaya such as government staff. Based on the experience on the internship I did a sales call. It is an activity promote the products to customers by coming to their office. They often use a meeting room and also the room. Video is the best way to promote 
La Lisa products because with video, the potential customer will be more interested when they see a moving picture rather than just a brochure. Some potential customers often asking if we have a video or not but we do not have it. They think, watching video is better than just looking at pictures, that is why they often ask for video.

I decided to pick the above problem as my Business Communication Final Project. Due to this Hotel not having proper promotional tool, I will make a promotional video to overcome this problem. This problem is a very important issue because addressing it with proper solution will help in attracting more customers in the future. This promotional video can be used as a promotional tool for the hotel to give further explanation regarding the products which is owned by the company. By having this video, the hotel can give more detailed information and highlight the hotel's strengths. Hence, people will not only know about what products that they offer in La Lisa, but they will also know where and why the need to buy the products. Through this video, people will learn more information because they know exactly about the unique selling proposition about the products that are being offered. Lastly, this could help Sales and Marketing Department to get more orders from new customers.

\section{METHODS}

There are several steps that I did to get the approve from the board of examiner for my Business Communication Final Project (BCFP) proposal. After finishing my internship, I made a proposal in which I want to discuss about the problems I found at La Lisa Hotel Surabaya which is related to Sales and Marketing team. After I had gotten the approve to apply my project at La Lisa Hotel Surabaya, I made a proposal for the board examiners. First, I mentioned the problems that I found during my intership in La Lisa Hotel Surabaya. Next , I gathered information both from books and online articles based on the background of the problems that company has. I did a research to understand the definition of a promotional video and branding. The references helped me to find out how to produce a good media in order to promote the company, which is by using a promotional video. The last thing that I did was I proposing my idea to my advisor. I explained about the company background which led me to propose in doing my project there, what can I do to benefit the company and what I could get later after I apply the project. After my idea is approved, I immediately work on my proposal which is shown in my progress report. This leads to the permission where I am able to do my project at La Lisa Hotel Surabaya.

After I got the permission from the board examiners and my managers, I had to get the approval from the company. Therefore, I gave them my proposal so that they would understand what I want to do for the company. I also explained the purpose of doing a promotional video, which is to help them to solve the problems that La Lisa Hotel is having, especially in sales tool section. I decided to make a promotional video for a sales tool to help them solve the problems. This is the steps I have taken in order to get the permission from the company.

First, I met the General Manager of La Lisa Hotel, Mrs. Rahmi Damayanti Pris. I explained the purpose of my BCFP where I have to make a project for research study. I gave her explanations about the project that I wanted to do. I showed her my proposal which includes the problems that I found in La Lisa Hotel. Then I offered her my solutions to solve the problems through a sales tool video. From our conversation, she showed an interest in my proposal and she would notify me as soon as possible.

I made a letter of agreement or a contract for them while waiting for their answer. After two weeks, I finally had the opportunity to meet the General Manager again. She asked me about my project and what will I feature on the video. Finally, she agreed to let me do my project at the 
company and I showed her the contract. Mrs. Rahmi asked for more time to read and discuss the contract with the team.

After she agreed with the contract, she chose the second choice from my offer and Rp. 6.500.000-, is given for this project. She wanted the professional models to appear in La Lisa Hotel promotional video. Two days later, I gave the letter of agreement to La Lisa Hotel Surabaya. At that time, my Marketing Manager, Ms.Oppy also signed the agremeent and gave me down payment Rp.3.000.000.-. They would pay off the rest when I give the final promotional video in $\mathrm{CD}$.

After my proposal got accepted by the company including the cost of making the project, I collected some information about the company. I studied directly to the Deluxe room and Family room in detail. I also asked further information about Deluxe room and Family room from the Sales and Marketing manager at La Lisa Hotel Surabaya. Then, I wrote an outline for each scene for Grand Superior room, Deluxe room and Family room for the promotional video. As soon as I finished making the content, I had a discussion with the General Manager, Creative Designer, Director of Sales, Sales Manager and Marketing Manager. They gave me advice to delete Grand Superior room scene and wanted to focus only on Deluxe room and Family room.

The first step to make the promotional video is finding the selling points of the Deluxe room and Family room and comparing them with the Grand Superior room. I collected the data of Grand Superior room from the last sales kit. I also asked the staffs about the size of room, price and facilities that customers will get by staying in the Grand Superior room. After that, I continued in collecting some data of the Deluxe room. After I have compiled the data, I compared the Grand Superior room and Deluxe room. By comparing them, I understood the uniqueness and selling points of the Deluxe room. Next, I collected the data about Family room and did some comparing between Deluxe room and Family Room to understand the selling points of the latter. To show the selling points and uniqueness, I categorized in to three parts; Room size, facilities and privacy. Next is the explanation of the selling points of each room.

\section{FINDINGS AND DISCUSSION}

The company where I did my internship at La Lisa Hotel. La Lisa Hotel is a 3.5 star hotel which is located on Nginden street number 82. This hotel has 121 rooms, 4 meeting rooms, pool, restaurant, coffee shop, and etc. This hotel has more spacious rooms than its rivals and one meeting room that can accommodate up to 200 people.

In La Lisa there are two main jobs which are sales and marketing. However, for my internship program, I will focus on the sales program. Based on my observation, there are 2 main competitors of La Lisa. The first one is Ibis Style. Ibis has played a big role in Indonesia's market. Ibis also has a well known brand image that can easily take down any other competitors. Other than Ibis there is also Santika. Looking at the price, La lisa and Santika's has similar price point. The price range for La Lisa starts from Rp 450.000 - 750.000, while Santika starts from Rp. 550.000 - 850.000. Looking at this fact, it appears that people tend to think twice which is better in term of price. Their target market includes business travelers, government people, and corporates. Surabaya. The problem is because the company does not have an appropriate tool to promote their products. They only use brochures that are not showing the uniqueness of the hotel. They only try to show all the rooms, meetings packages, facilities which are very standart like other hotels, without focusing on the unique selling point of the hotel itself. Thus, people are reluctant to visit or stay at La Lisa Hotel. Throughout my internship, I spread the questionnaire to the following people like female and male, age around 30-50 years old. The target market are business people all over Indonesia. 
First, the promotional video will help La Lisa Hotel to increase the sales. With this promotional video, sales executives would not have to do a preliminary visit. Instead, they could just send the video along with the proposal to the prospect clients. If the clients are interested, the sales executives then proceed to visit the client to give a deeper understanding of the hotel. By using this video, the sales executives will not have much trouble in visualizing the hotel as the promotional video itself contained an immersive visualization of each room, hotel facilities, and the meeting room suitable for clients' needs.

The second one, the promotional video will make La Lisa well known among its competitors. This promotional video will be published in social media, so people can know more about the strengths of the hotel rather that the competitors.

For the Business Communication Final Project, I decided to make a promotional video. The reason why I make this promotional video is because the content in the video attract customers and make them have better understanding about La Lisa products specially meeting room and room. Then, doing a promotion through a video is more effective and fun compared to the last sales kit where it came in written form. Therefore, it is essential to make this promotional video to help the Sales and Marketing team for selling both meeting room and room.

I applied this theory based on medium.com there are 8-steps for making good video. This steps are really helpful for starting make a promotional video for La Lisa Hotel Surabaya. This theory helps to how get the fits model in the video, how to find the theme of the video that give a good new image to the listeners.

For the content of promotional video, I choose three important components, such as the meeting room, the room, and other facilities. First, I decided to use those components because they contain a lot of information needed by the potential customers in order to know more about meeting room. Customers are usually do not know about both Deluxe room. Those components are considered as very important to be included in promotional video.

In addition, the order of the components included in the promotional video also becomes one of the important points that will be my consideration in making this promotional video. Based on the order of importance from not-so important into the most important scene, I put the scene " The Outside Building and the Lobby" in the first order because the scene only shows the image of La Lisa from outside. It will help customers to know the impression of the building of La Lisa Hotel Surabaya that is simple and modern. After that, I show the scene inside the shuttle car to show the special service from La Lisa Hotel.

Second, I put the scene about "Nusantara meeting room". I put this in the second scene because it is pretty important for the customers. This scene does not only show the image of the meeting room, but also the subtitle about the information of this meeting room. The images and the information help the customers to be aware that Nusantara meeting room is one of the benefits for meeting room package. The scene that I show the models, doing activity inside Nusantara meeting room. I asked them to have a talk in the meeting room.

Third, I put the scene about "Deluxe room" which is important in this promotional video. This scene shows the image and information about the uniqueness of Deluxe room. This will make the customers understand the advantages of staying in the Deluxe room. The scene shows the model enjoying the spacious room.

Fourth, I put the scene about "Hotel Facilities" which I capture the pool and coffee corner. I believe that showing another side of the meeting room, which is the supporting details about the hotel will help the potential customers to get deeper understanding about why they need to stay 
at this hotel is not only about the main thing either the room or meeting room, but the facilities. Customers especially business people need to understand that they also need to refresh theirselves from the hectic days with a convinient ambience at the hotel. If a hotel only serves a meeting room and the room, I believe they will reluctant to make a second visit.

Based on the order of importance, the customers who watch this promotional video will have an impression of getting more luxurious atmosphere in the end of video. Starting from The building and lobby of the hotel, Executive Dynasty Lounge, Diamond suite and the last is President suite.

\section{CONCLUSION}

For my Business Communication Final Project (BCFP), I decide to make a Promotional Video for La Lisa, a 3.5 star hotel. The problem that they have is they do not have an effective promotional tool to promote the hotel. Thus, it makes the sales person could not attract new customers. Therefore, in order to solve this problem, La Lisa needs to fix their problem as soon as possible. Up until now, La Lisa only have their printed brochure while in this digital era, people rarely see the brochure of the company. Besides, the brochure is limited while promotional video is unlimited. It can be reached by many people anywhere and anytime. A video can help the hotel to increase the sales better because promotional video can reach a broader target market.

In this video, it will focus more on the meeting room and other supporting details such as the spacious rooms, coffee corner, and pool. It will be easier to attract the potential customers that are mostly government people why they need to choose La Lisa hotel instead of other.

In this video, it will show a guy who is a business man that doing a business trip to Surabaya and choose La Lisa hotel. He will use the meeting room with his colleagues, enjoy to rest the room, have a coffee break, and enjoying the rest of the day at the pool. People that see this video will understand clearly the point that why they need to stay at this hotel.

For the next students of English for Business Communication of Petra Christian University who want to take the similar Business Communication Final Project (BCFP) as mine, I want to suggest that it will be better if the students build a good relationship between students, students supervisor, and the employee during your internship period. Try to explain the goal of the internship to them that the students will contribute a project that will benefits them in the future. Then, identify the problem and find the uniqueness through google form or interviewing the customers and workers. Next, after the students know and understand the problem and the strength, or the uniqueness of the company, the students can come up with your final project idea. I suggest getting an immediate approval either from the examiners or the supervisor because when they give an approval, the students can immediately meet the person who will take the decision from the company. At last, the students need to present the idea immediately to the decision to the board of managers in the company and make them sign the contract as soon as possible. Having a good communication skill is very helpful to avoid misunderstanding between parties. Hope that the students can learn many things through this project, good luck.

\section{REFERENCE}

Bashin, Hitesh. (2017). Promotional Mix: What are the different types of promotion? Retrieved November 15, 2018, from https://www.marketing91.com/promotional-mix/

Cass, Jacob. (2018). 8 Benefits of Branding: Why you need a strong brand? Retrieved November 23, 2018, from https://justcreative.com/2018/09/27/benefits-of-branding/ 
Gelder, S. V. (2003). Global Brand Strategy:Unlocking Branding Potential Across Countries, Culture \& Market.Great Britain and the United States: Kogan Page Limited

Healey, Matthew. 2008. What is Branding? United Kingdom, Hove: RotoVision SA.

Hidayat, W. (2014). Pengguna Internet Indonesia Nomor Enam Dunia. Retrieved September 10, 2018, from https://kominfo.go.id/content/detail/4286/pengguna-internetindonesia-nomor-enam- dunia/0/sorotan_media

Karpenisi,V. (2015) Retrieved from

<http://brandingeu.com/sites/default/files/Branding\%20EU\%20Ebook\%20EN.pdf >

Laudon, K.C., \& Traver, C.G. (2010). E-commerce. Business, technology, society. New York. Pearson Prentice Hall

McCabe, S. (2009). Marketing Communications in Tourism and Hospitality: Concepts, Strategies, and cases. Oxford:Butterworth-Heinemann

Magurie,Annie. (2016). Retrieved from < https://medium.com/swlh/how-to-create-promotionalvideo-707fa7a63019>

Semenik, Richard J. 2002. Promotion and integrated marketing communication. Canada: Dave Shaut.

Sodhi, Rajan. (2006). 6 practical steps to bringing your brand to life. Retrieved November 15, 2018, from http://rsodhi.blogspot.com/

http://www.dictionary.com/browse/tool (2013). Tools

https://www.merriam-webster.com/dictionary/video (2019).Video

Wheeler, Alina. 2013. Designing brand identity: An essential guide for the whole branding team. Canada: John Wiley \& Sons, Inc. 